\title{
Some wild fruits from amazon biodiversity: composition, bioactive compounds, and characteristics
}

\author{
${ }^{1}$ Sousa, H.M.S., ${ }^{1}$ Leal, G.F., ${ }^{2}$ Damiani, C., ${ }^{3}$ Borges, S.V., ${ }^{1}$ Freitas, B.C. and \\ ${ }^{1, *}$ Martins, G.A.S. \\ ${ }^{1}$ Laboratory of Kinetics and Process Modeling, Federal University of Tocantins, Palmas, TO, Brazil. \\ ${ }^{2}$ School of Agronomy, Federal University of Goiás, Campus Samambaia, Goiânia, GO, Brazil. \\ ${ }^{3}$ Department of Food Science, Federal University of Lavras, Lavras, MG, Brazil.
}

\begin{abstract}
Article history:
Received: 28 November 2020

Received in revised form: 23

January 2021

Accepted: 2 April 2021

Available Online: 15 August 2021
\end{abstract}

Keywords:

Legal Amazon,

Functional properties,

Exotic fruits,

Nutritional characteristics,

Phenolic compounds

DOI:

https://doi.org/10.26656/fr.2017.5(5).687

\begin{abstract}
Brazil is one of the countries that share a part of the Amazon region that has been called Legal Amazon. Amazon forest offers the most extraordinary biodiversity of flora and fauna on the planet and, on its surface, can cohabit $50 \%$ of the total existing living species. According to some botanists, it would contain about $16-20 \%$ of the species that exist today. This region has native fruits with antioxidants and antiproliferative activities already reported by some authors. Consumption of these fruits would be an alternative because they are good sources of nutritional constituents, such as minerals, fibre, vitamins, water, and caloric content. However, the number of scientific studies related to their health benefits is still low. Eugenia stipitata, Myrciaria dubia H. B. K. (Mcvough), Endopleura uchi (Huber) Cuatrecasas, Eugenia punicifolia (Kunth) D.C and Garcinia madruno. Among the main compounds reported are the most interesting groups: phenolic compounds, unsaturated fatty acids, carotenoids, phytosterols, and tocopherols, flavonoids, vitamin $\mathrm{B}$, vitamin $\mathrm{A}$, and vitamin $\mathrm{C}$, and carotenoids. The main beneficial effect of the Amazon fruits is the antioxidant effect; other functional properties as medicinal, antimicrobial, antimutagenic, antigenotoxic, antigenotoxic, and antiinflammatory, antinociceptive, antidiabetic, and gastroprotective, are also reported. Therefore, these fruits can be considered a valuable source of functional foods due to their phytochemical compositions and their corresponding antioxidant activities.
\end{abstract}

\section{Introduction}

Statistics show that more than 820 million people worldwide suffer from a lack of food that meets the nutritional requirements necessary for healthy living (FAO et al. 2019). Among the factors that generate this problem are the inequality of income distribution and the difficulty of accessibility to food, which causes a significant portion of the world population to be in a state of food insecurity (FAO, 2020).

The consumption of fruits is an alternative to enrich the diet because they are sources of nutritional constituents, such as minerals, fibre, vitamins, water, and caloric content (Andrade Jr and Andrade, 2014). However, native fruits from South America still do not have sufficient studies related to their health benefits compared to fruits from Europe and North America (Rufino et al. 2010; Gironés-Vilaplana et al., 2014). Brazil is the second centre in the rank for tropical fruit worldwide, concentrating just in the Brazilian Amazon approximately $40 \%$ of edible fruit-producing species. The majority is obtained through the extraction (EMBRAPA, 2016).

The Amazon rainforest reflects a rich diversity of flora and fauna, serving as a refuge to about $20 \%$ of all known species (Ministry of the Environment, 2019) This biome's endemic fruits are consumed in large quantities by most native populations, and access to these products happens quickly in local markets (Matos et al., 2019). These fruits are generally recognized as 'exotic fruits' because they have unusual characteristics such as shape, colour, and flavour (Chang et al., 2019). The wide availability of different bioactive and therapeutic compounds, in addition to the wide variety of species in the Amazon Biome, has attracted worldwide attention from researchers and food industries to those seeking alternatives for a healthy lifestyle (Lima Yamaguchi et al., 2015).

Within this scenario, this review seeks to bring 
information about some fruits from Amazon Forest with high technological and pharmaceutical potential, highlighting aspects of their composition, bioactive compounds, and therapeutic properties, but which are not so well known by the scientific community. For this purpose, the literature data on the aspects already mentioned of Amazonian fruits published between 1993 and 2020 on digital platforms such as ScienceDirect, ResearchGate, SciELO, Scopus, EMBRAPA, and Google Scholar were grouped, with the primary material collected through a search in English, Spanish and Portuguese.

\section{Main characteristics of the fruits from the Amazon biome}

\subsection{Araçá-boi (Eugenia stipitata)}

From the Myrtaceae family, the araçá-boi (Eugenia stipitata) is a fruit of climacteric behaviour, found in the western Amazon, Ecuador, and Guyana. Trees from this fruit develop in deep and fertile soil, the fruiting occurs three times a year, and the harvest can occur 38 days after the flowering process (Neves et al., 2015; AvilaSosa et al., 2019). With a globular berry shape measuring about $12 \mathrm{~cm}$ in diameter, the fruit can weigh up to $300 \mathrm{~g}$ and has a velvety and thin skin, canary yellow colour, ranging from 4 to 10 seeds per unit, and succulent and acid pulp (Baldini et al., 2017; Bohry et al., 2019).

Many of the fruit species that belong to the Myrtaceae family are used as natural medicines by the local population. This healing art is traditionally transmitted from generation to generation, and it is used to treat inflammatory conditions, intestinal disorders, high blood pressure, and diabetes (Reynertson et al., 2008; Leite-Legatti et al., 2012; Malta et al., 2012; NeriNuma et al., 2013).

The araçá-boi tends to show moisture higher than $90 \%$ and a lipid content lower than $0.3 \%$, thus characterizing an ideal non-caloric fruit for the production of juices and jams. Carbohydrates stand out as the main component, representing about $50 \%$ of dry weight, with fructose as the primary sugar found. The soluble solids content is around $4.5^{\circ} \mathrm{Bx}$; the acid flavour is derivated from the low $\mathrm{pH}$ of 2.5. The protein content reported in the literature is low, and the percentage of minerals (Neves et al., 2015; Negri et al., 2016; AvilaSosa et al., 2019; Berni et al., 2019).

With its acid flavour, the fresh consumption of this fruit is low. Still, its industrial processing has been explored to enrich the final products due to its beneficial health components (Neves et al., 2015). An example of this is that papaya jam production with araçá-boi obtained wide sensory acceptance among tasters (Viana et al., 2012). Likewise, supplementation of apple nectar with araça-boi pulp increased the product's antioxidant activity (Baldini et al., 2017).

Many bioactive compounds (Table 1) are present in the araça-boi, and among these, carotenoids as all-trans- $\beta$ -carotene, lutein, and esters such as palmitic acids, can be highlight (Garzón et al., 2012; Berni et al., 2019). The reported content of phenolic compounds and Vitamin C is high. However, the ripening decreases such compounds' concentration (Neves et al., 2015). The highest antioxidant capacity in the fruit occurs in its unripe state, and the tendency to fall as it matured (Garzón et al., 2012; Cuellar et al., 2013). Besides that, antimutagenic and antigenotoxic activity was found (Neri-Numa et al., 2013). In vivo studies have determined the anti-inflammatory effects of E. stipitata extract, a result related to phenolic compounds in its composition (Soares et al., 2019).

\subsection{Cати-сати (Myrciaria dubia H. B. K. (Mcvough))}

Popularly known as camu-camu, caçari, or araçád'água, the Myrciaria dubia H. B. K. (McVough) is a small tree that belongs to the Myrtaceae family. It is present over practically the entire Amazon region. The trees have an average height, not exceeding $3 \mathrm{~m}$, and are found in the non-domesticated state, mainly on the riverbanks and lakes with dark-colored water (INPA, 2012). The trees produce rounded fruits with an average mass ranging from 2.2 to $13.5 \mathrm{~g}$, flat and shiny exterior, diameter ranging from 1.0 to $3.8 \mathrm{~cm}$, and containing three to four seeds per fruit unit. When in the ripening state, its color varies from dark red to purple, fruiting between November to March (Chagas et al., 2012; Langley et al., 2015; Neves et al., 2017).

In some Peru regions, camu-camu is widely used in traditional medicine to treat respiratory diseases, cataracts, depression, flu, gingivitis, infertility, migraine, osteoporosis, and malaria (Castro et al., 2018). Yazawa et al., (2011) proposed in their study that the fruit seed extract has potential as a source of betulinic acid, which as a functional food, prevents diseases linked to the immune system, in addition to having antimicrobial and anti-diabetic properties (Myoda et al., 2010; Fujita et al., 2013).

The fruits are useful minerals (Table 2) because they contain sodium, potassium, calcium, zinc, magnesium, manganese, and copper. They also have small amounts of pectin and starch in their composition. The pulps have different types of fatty acids, mainly stearic, linoleic, and oleic. Highlighted sugars are glucose and fructose, and they also have various kinds of amino acids with an 
Table 1. Chemical, nutritional and bioactive composition of Araçá-boi (Eugenia stipitata)

\begin{tabular}{|c|c|c|}
\hline Components & Part of the plant & References \\
\hline Moisture & Pulp and waste & Baldini et al. (2017); Barros et al. (2017); Berni et al. (2019) \\
\hline Soluble solids $\left({ }^{\circ} \mathrm{Bx}\right)$ & Pulp and waste & Baldini et al. (2017); Barros et al. (2017); Bohry et al. (2019) \\
\hline $\mathrm{pH}$ & Pulp and waste & Baldini et al. (2017); Barros et al. (2017); Bohry et al. (2019) \\
\hline Total titratable acidity & Pulp and waste & Baldini et al. (2017); Barros et al. (2017); Bohry et al. (2019) \\
\hline Ashs & Pulp & Baldini et al. (2017); Berni et al. (2019) \\
\hline Lipids & Pulp & Baldini et al. (2017); Berni et al. (2019) \\
\hline Proteins & Pulp & Baldini et al. (2017); Berni et al. (2019) \\
\hline Total fibers & Pulp & Baldini et al. (2017); \\
\hline Soluble fibers & Pulp & Baldini et al. (2017); Berni et al. (2019) \\
\hline Insoluble fibers & Pulp & Baldini et al. (2017); Berni et al. (2019) \\
\hline Digestible carbohydrates & Pulp & Baldini et al. (2017); \\
\hline Carbohydrates & Pulp & Berni et al. (2019) \\
\hline Color & Pulp, peel & Bohry et al. (2019) \\
\hline Vitamin C & Pulp & Neves et al. (2015) \\
\hline \multicolumn{3}{|l|}{ Carotenoids } \\
\hline all-trans- $\beta$-carotene & Pulp & Berni et al. (2019) \\
\hline all-trans- $\alpha$-carotene & Pulp & Berni et al. (2019) \\
\hline$\beta$-cryptoxanthin & Pulp & Berni et al. (2019) \\
\hline cis- $\beta$-carotene & Pulp & Berni et al. (2019) \\
\hline Violaxanthin & Pulp & Berni et al. (2019) \\
\hline Lutein & Pulp & Berni et al. (2019) \\
\hline Zeaxanthin & Pulp & Berni et al. (2019) \\
\hline all-trans- $\gamma$-carotene & Pulp & Berni et al. (2019) \\
\hline cis- $\gamma$ carotene & Pulp & Berni et al. (2019) \\
\hline all-trans-lycopene & Pulp & Berni et al. (2019) \\
\hline Retinol activity equivalents & Pulp & Berni et al. (2019) \\
\hline \multicolumn{3}{|l|}{ Minerals } \\
\hline $\mathrm{K}$ & Pulp & Leterme et al. (2006) \\
\hline$P$ & Pulp & Leterme et al. (2006) \\
\hline S & Pulp & Leterme et al. (2006) \\
\hline $\mathrm{Ca}$ & Pulp & Leterme et al. (2006) \\
\hline $\mathrm{Mg}$ & Pulp & Leterme et al. (2006) \\
\hline $\mathrm{Cl}$ & Pulp & Leterme et al. (2006) \\
\hline $\mathrm{Na}$ & Pulp & Leterme et al. (2006) \\
\hline $\mathrm{Co}$ & Pulp & Leterme et al. (2006) \\
\hline $\mathrm{Cu}$ & Pulp & Leterme et al. (2006) \\
\hline $\mathrm{Fe}$ & Pulp & Leterme et al. (2006) \\
\hline $\mathrm{Zn}$ & Pulp & Leterme et al. (2006) \\
\hline $\mathrm{Mn}$ & Pulp & Leterme et al. (2006) \\
\hline $\mathrm{Cr}$ & Pulp & Leterme et al. (2006) \\
\hline $\mathrm{Se}$ & Pulp & Leterme et al. (2006) \\
\hline $\mathrm{Ni}$ & Pulp & Leterme et al. (2006) \\
\hline \multicolumn{3}{|l|}{ Phenolic compounds } \\
\hline Vanillic acid-O-hexoside & Waste & Soares et al. (2019) \\
\hline Ellagic acid & Waste & Soares et al. (2019) \\
\hline Coumaric acid & Waste & Soares et al. (2019) \\
\hline Acid-Ohexoside & Waste & Soares et al. (2019) \\
\hline Catechin & Waste & Soares et al. (2019) \\
\hline Epicatechin & Waste & Soares et al. (2019) \\
\hline Gallocatechin-gallate & Waste & Soares et al. (2019) \\
\hline Dihydroquercetin glucoside & Waste & Soares et al. (2019) \\
\hline Naringin hydrate & Waste & Soares et al. (2019) \\
\hline Eriodictyol & Waste & Soares et al. (2019) \\
\hline Tellimagrandin II & Waste & Soares et al. (2019) \\
\hline Pterocaryanin C & Waste & Soares et al. (2019) \\
\hline Casuarictin & Waste & Soares et al. (2019) \\
\hline Potentillin & Waste & Soares et al. (2019) \\
\hline
\end{tabular}


Table 2. Chemical, nutritional and bioactive composition of Camu-camu (Myrciaria dubia H. B. K. (Mcvough)).

\begin{tabular}{|c|c|c|}
\hline Components & Part of plant & References \\
\hline Moisture & Pulp & Alves et al. (2002); Justi et al. (2000); Zapata and Dufour (1993) \\
\hline Carbohydrate & Pulp & Alves et al. (2002); Justi et al. (2000); Zapata and Dufour (1993) \\
\hline Monosaccharides & Pulp & Alves et al. (2002); Justi et al. (2000); Zapata and Dufour (1993) \\
\hline Protein & Pulp & Alves et al. (2002); Justi et al. (2000); Zapata and Dufour (1993) \\
\hline Ashs & Pulp & Alves et al. (2002); Justi et al. (2000); Zapata and Dufour (1993) \\
\hline Crude fiber & Pulp & Alves et al. (2002); Justi et al. (2000); Zapata and Dufour (1993) \\
\hline Lipids & Pulp & Alves et al. (2002); Justi et al. (2000); Zapata and Dufour (1993) \\
\hline Total soluble solids $\left({ }^{\circ} \mathrm{Bx}\right)$ & Pulp & Alves et al. (2002); Justi et al. (2000); Zapata and Dufour (1993) \\
\hline Total titrable acidity & Pulp & Alves et al. (2002); Justi et al. (2000); Zapata and Dufour (1993) \\
\hline $\mathrm{pH}$ & Pulp & Alves et al. (2002); Justi et al. (2000); Zapata and Dufour (1993) \\
\hline Starch & Pulp & Alves et al. (2002); Justi et al. (2000); Zapata and Dufour (1993) \\
\hline Pectin & Pulp & Alves et al. (2002); Justi et al. (2000); Zapata and Dufour (1993) \\
\hline Citric acid cycle intermediates & Pulp & Alves et al. (2002); Justi et al. (2000); Zapata and Dufour (1993) \\
\hline \multicolumn{3}{|l|}{ Polyphenols } \\
\hline Polyphenols & Pulp, peel & Fracassetti et al. (2013); Fujita et al. (2013) \\
\hline Ellagic acid and derivatives & Leaves & Ueda et al. (2004) \\
\hline 1-methylmalate & Fruit juice & Akachi et al. (2010) \\
\hline C-glycosidic ellagitannins & Peel, seed & Kaneshima et al. (2016) \\
\hline Betulinic acid & Seed & Yazawa et al. (2011) \\
\hline \multicolumn{3}{|l|}{ Essential Aminoacids } \\
\hline Phenylalanine & Pulp & Zapata and Dufour (1993) \\
\hline Threonine & Pulp & Zapata and Dufour (1993) \\
\hline Valine & Pulp & Zapata and Dufour (1993) \\
\hline Leucine & Pulp & Zapata and Dufour (1993) \\
\hline Isoleucine & Pulp & Zapata and Dufour (1993) \\
\hline Lysine & Pulp & Zapata and Dufour (1993) \\
\hline Histidine & Pulp & Zapata and Dufour (1993) \\
\hline Methionine & Pulp & Zapata and Dufour (1993) \\
\hline \multicolumn{3}{|l|}{ Essential Fatty Acids } \\
\hline Stearic & Pulp & Justi et al. (2000) \\
\hline Linoleic & Pulp & Justi et al. (2000) \\
\hline Oleic & Pulp & Justi et al. (2000) \\
\hline$\gamma$-linolenic & Pulp & Justi et al. (2000) \\
\hline$\alpha$-linolenic & Pulp & Justi et al. (2000) \\
\hline Tricosanoic & Pulp & Justi et al. (2000) \\
\hline Eicosadienoic & Pulp & Justi et al. (2000) \\
\hline
\end{tabular}

\begin{tabular}{lcc}
\hline Vitamins & \\
\hline Vitamin C & Pulp & Alves et al. (2002); Castro et al. (2015); Zapata and Dufour \\
(1993); Rodrigues and Marx (2006); Rufino et al. (2010); Chirinos \\
et al. (2010)
\end{tabular}


Table 2 (Cont.). Chemical, nutritional and bioactive composition of Camu-camu (Myrciaria dubia H. B. K. (Mcvough)).

\begin{tabular}{|c|c|c|}
\hline Components & Part of plant & References \\
\hline \multicolumn{3}{|l|}{ Minerals } \\
\hline $\mathrm{K}$ & Pulp & Justi et al. (2000); Zapata and Dufour (1993) \\
\hline $\mathrm{PO}_{4}$ & Pulp & Justi et al. (2000); Zapata and Dufour (1993) \\
\hline $\mathrm{SO}_{4}$ & Pulp & Justi et al. (2000); Zapata and Dufour (1993) \\
\hline $\mathrm{Ca}$ & Pulp & Justi et al. (2000); Zapata and Dufour (1993) \\
\hline $\mathrm{Mg}$ & Pulp & Justi et al. (2000); Zapata and Dufour (1993) \\
\hline $\mathrm{Cl}$ & Pulp & Justi et al. (2000); Zapata and Dufour (1993) \\
\hline $\mathrm{Na}$ & Pulp & Justi et al. (2000); Zapata and Dufour (1993) \\
\hline Co & Pulp & Justi et al. (2000); Zapata and Dufour (1993) \\
\hline $\mathrm{Cu}$ & Pulp & Justi et al. (2000); Zapata and Dufour (1993) \\
\hline $\mathrm{Fe}$ & Pulp & Justi et al. (2000); Zapata and Dufour (1993) \\
\hline $\mathrm{Zn}$ & Pulp & Justi et al. (2000); Zapata and Dufour (1993) \\
\hline $\mathrm{Al}$ & Pulp & Justi et al. (2000); Zapata and Dufour (1993) \\
\hline $\mathrm{Mn}$ & Pulp & Justi et al. (2000); Zapata and Dufour (1993) \\
\hline B & Pulp & Justi et al. (2000); Zapata and Dufour (1993) \\
\hline $\mathrm{Br}$ & Pulp & Justi et al. (2000); Zapata and Dufour (1993) \\
\hline $\mathrm{Cr}$ & Pulp & Justi et al. (2000); Zapata and Dufour (1993) \\
\hline Mo & Pulp & Justi et al. (2000); Zapata and Dufour (1993) \\
\hline $\mathrm{Se}$ & Pulp & Justi et al. (2000); Zapata and Dufour (1993) \\
\hline \multicolumn{3}{|l|}{ Carotenoids } \\
\hline Neoxanthin & Pulp & Zanatta and Mercadante (2007) \\
\hline cis-neoxanthin & Pulp & Zanatta and Mercadante (2007) \\
\hline Violaxanthin(all-trans*+ cis) & Pulp & Zanatta and Mercadante (2007) \\
\hline Luteoxanthin & Pulp & Zanatta and Mercadante (2007) \\
\hline Flavoxanthin*+mixture & Pulp & Zanatta and Mercadante (2007) \\
\hline 5,6-epoxy-lutein & Pulp & Zanatta and Mercadante (2007) \\
\hline 5,8-epoxy-zeaxanthin & Pulp & Zanatta and Mercadante (2007) \\
\hline 5,6-epoxy-zeaxanthin & Pulp & Zanatta and Mercadante (2007) \\
\hline All-trans-lutein & Pulp & Zanatta and Mercadante (2007) \\
\hline Zeaxanthin & Pulp & Zanatta and Mercadante (2007) \\
\hline Sintaxanthin & Pulp & Zanatta and Mercadante (2007) \\
\hline b-Cryptoxanthin(all-trans $*+$ cis) & Pulp & Zanatta and Mercadante (2007) \\
\hline 5,8-Epoxy-b-carotene & Pulp & Zanatta and Mercadante (2007) \\
\hline$\beta$-carotene & Pulp & Zanatta and Mercadante (2007) \\
\hline
\end{tabular}

emphasis on valine, serine, glutamate, and leucine. the polyphenol compounds are anthocyanins, total Among the organic acids, there is an expressive presence of critical acid when the fruit is not fully ripe and malic acid when it ripened. Camu-camu has significant amounts of $\mathrm{B}$ vitamins, vitamin $\mathrm{A}$ and vitamin $\mathrm{C}$ content 60 times higher than that found in oranges, which according to RDC n 269 of 2005 (Brazil, 2005), this quantity are 66 times higher than the recommended daily intake (Justi et al., 2000; Alves et al., 2002; Rodrigues and Marx, 2006; Akter et al., 2011; Hernández et al., 2011; Castro, Cobos, Maddox et al., 2015; Castro, Maddox, Cobos et al., 2015).

The amount of bioactive compounds changes as the fruit ripens. Carotenoids, flavonoids, anthocyanins, and vitamin $\mathrm{C}$ are in higher concentrations before harvest (Avila-Sosa et al., 2019). All-trans-lutein is the carotenoid in greater abundance (Zanatta, 2007). Among phenolics, flavonols, and flavonoids (Zanatta et al., 2005; Reynertoson et al., 2008; Chirinos et al., 2010; Goncalves et al., 2010; Myoda et al., 2010; Rufino et al. 2010). Camu-camu shows a high antioxidant capacity (Akter et al., 2011; Avila-Sosa et al., 2019) and antimicrobial and antigenotoxic characteristics (Chirinos et al., 2010; Da Silva et al., 2012; Fujita et al., 2013).

The fruit is not consumed because of the high acidity in its natural form, except for the indigenous people. This happens due to the high content of L-ascorbic acid and phenolic acid, which affect its palatability (Langley et al., 2015). Although there is evidence of its beneficial effect on health, fruit juice still has high sensory rejection rates (Vidigal et al., 2011). However, these acidic characteristics have been explored for yogurt production, obtaining high acceptability (Aguiar and Do 
Amaral, 2015).

The camu-camu can be considered a food additive since their lyophilized aqueous extract increases the final product's antioxidant activity when added to milk products. This higher antioxidant activity decreased the necessity of preservatives in this type of food (Gaglio et al., 2019; Fidelis et al., 2020). The camu-camu yogurt containing its seed extract obtained an acceptance rate of $84 \%$, demonstrating that the camu-camu seed extract can be a potential ingredient for addition to dairy products (Fidelis et al., 2020). Thus, this type of food is suitable in a series of new approaches to make them naturally healthy, using natural extracts in the production of dairy foods (Zikiou and Zidoune, 2019).

\subsection{Uxi (Endopleura uchi (Huber) Cuatrecasas)}

Popularly known as uchi, uxi, axuá, uchi-pucu, uxiamarelo, uxi-liso, and uxi-ordinário (Sá et al., 2015), Endopleura uchi (Huber) Cuatrecasas is a botanical species belonging to the Humiriaceae family and is present throughout the Brazilian Amazon basin. Developing on dry land, the fruit trees of Endopleura uchi (Huber) Cuatrecasas can reach $30 \mathrm{~m}$ in height, with trunks of rigid reddish wood, commonly used in construction. After the end of the rainy season, flowering begins between June and July. The ripening of the fruits occurs between December to July (Marx et al., 2002). The fruits have the shape of an oblong-ellipsoid drupe, diameter varying from 5 to $7 \mathrm{~cm}$, rough yellow-orange skin, weighing about $60 \mathrm{~g}$, and the pulp is the only edible portion (Neves et al., 2015; Lima et al., 2020).

Tea from the bark of the uxizeiro tree trunk is used by the inhabitants of the Amazon region to treat diabetes, arthritis, rheumatism, cholesterol control, and to treat menstrual disorders (Oliveira et al., 2017). Infusion of $E$. uchi peel has antidiabetic activity due to a high content of phenolic compounds, specifically bergenine and its derivatives (De Abreu et al., 2008). Bergenin acts as an inhibitor of $\alpha$-glucosidase (AGIs), an enzyme that acts in the catabolism of carbohydrates to reduce the postprandial peaks of glucose and insulin (Silva and Teixeira, 2015).

Endopleura uchi peel extracts showed a better option for diabetes treatment compared to other plants that have already been studied for this, such as Cecropia obtusifolia, Malmea depressa, Acosmium panamense, and Spergularia rubra (Vinholes et al., 2011). Kumar et al. (2012) tested the type 2 antidiabetic activity of bergenin in diabetic rats. The results obtained allowed the authors to conclude that bergenin has significant antidiabetic, hypolipidemic, and antioxidant activity in type 2 diabetic rats.
Regarding antibacterial activity, Pseudomonas aeruginosa showed a high sensitivity for the infusion of E. uchi peel. However, Bacillus cereus and Micrococcus luteus showed greater sensitivity to the E. uchi hydroethanolic extract (Silva and Teixeira, 2015). Politi et al. (2012) reported that $E$. uchi infusion extracts could have an inhibition potential against $S$. aureus. The antibacterial activity of $E$. uchi may be associated with the presence of phenolic compounds. It is also possible that there are other bioactive compounds in the extracts, which interfere with the real antimicrobial potential, such as tannins and organic acids (Silva et al., 2009; Taveira et al., 2010).

Among other benefits of E. uchi is the ability to act in the inhibition of pancreatic lipase (Yun, 2010; Sukhdev and Singh, 2013) and the formation of lipoproteins (Klop et al., 2013); thus becoming a potential for preventing obesity and hyperlipidemia (Hyacienth et al., 2019). This ability to inhibit pancreatic lipase may be directly related to the content of polyphenols, especially flavonoids, which can have an essential role in preventing obesity and also preventing serum lipoproteins oxidation (Oliveira et al., 2017). Phenolic compounds interact with specific amino acids at the lipase catalytic active site, forming stable complexes, inactivating the enzyme (Pereira et al., 2011; Souza et al., 2011, Shikov et al., 2012, Lunagariya et al., 2014).

As for the proximal composition (Table 3), the uxi has a moisture content of less than $50 \%$ in all fruit portions. The pulp shows high levels of total lipids, emphasizing the presence of linoleic and $\alpha$-linolenic acids, and its peel similarly has significant levels of palmitic acid and oleic acid (Berto et al., 2015). Among the mineral compounds in the whole fruit, magnesium is present in high concentrations, which is an essential constituent of bones and teeth, which offers the population easy access to a resource that brings permanent benefits to the health and quality of life of those who consume (Elige et al., 2012; Berto et al., 2015). Fractions of sugars are relatively low, with the highest concentration being fructose. Similarly, organic acids are also present in low amounts. The crude protein fraction is low, which differs from the total dietary fiber, which achieves a surprising concentration for fruits, emphasizing pectin (Marx et al., 2002).

The content of ascorbic acid present in the fruit is evident. However, it is worth noting that the storage time deteriorates the ascorbic acid. This deteriorating behavior with storage is opposite to what occurs with the total phenolic content (Marx et al., 2002; Neves et al., 2015), where bergenia is the more abundant compound 
Table 3. Chemical, nutritional and bioactive composition of Uxi (Endopleura uchi (Huber) Cuatrecasas).

\begin{tabular}{|c|c|c|}
\hline Components & Part of plant & References \\
\hline Moisture & Pulp, seed and peel & Marx et al. (2002); Berto et al. (2015) \\
\hline Raw protein & Pulp, seed and peel & Marx et al. (2002); Berto et al. (2015) \\
\hline Lipid fraction & Pulp, seed and peel & Marx et al. (2002); Berto et al. (2015) \\
\hline Acid content & Pulp & Marx et al. $(2002)$ \\
\hline Soluble solids ( ${ }^{\circ}$ Brix) & Pulp and peel & Neves et al. (2015) \\
\hline Soluble sugars & Pulp and peel & Neves et al. (2015) \\
\hline Titratable acidity & Pulp and peel & Neves et al. (2015) \\
\hline \multicolumn{3}{|l|}{ Carbohydrates } \\
\hline Available carbohydrates & Pulp, seed and peel & Marx et al. (2002); Berto et al. (2015) \\
\hline Glucose & Pulp & Marx et al. $(2002)$ \\
\hline Fructose & Pulp & Marx et al. (2002) \\
\hline Saccharose & Pulp & Marx et al. (2002) \\
\hline Starch & Pulp & Marx et al. (2002) \\
\hline Pectin & Pulp & Marx et al. (2002) \\
\hline \multicolumn{3}{|l|}{ Organic acids } \\
\hline Citric acid & Pulp & Marx et al. (2002) \\
\hline Maleic acid & Pulp & Marx et al. (2002) \\
\hline \multicolumn{3}{|l|}{ Fatty acids } \\
\hline Myristic acid & Pulp, seed and peel & Marx et al. (2002); Berto et al. (2015) \\
\hline Palmitic acid & Pulp, seed and peel & Marx et al. (2002); Berto et al. (2015) \\
\hline Palmitoleic acid & Pulp, seed and peel & Marx et al. (2002); Berto et al. (2015) \\
\hline Stearic acid & Pulp, seed and peel & Marx et al. (2002); Berto et al. (2015) \\
\hline Oleic acid & Pulp, seed and peel & Marx et al. (2002); Berto et al. (2015) \\
\hline Linoleic acid & Pulp, seed and peel & Marx et al. (2002); Berto et al. (2015) \\
\hline Linolenic acid & Pulp, seed and peel & Marx et al. (2002); Berto et al. (2015) \\
\hline Eicosanoic acid & Pulp, seed and peel & Marx et al. (2002); Berto et al. (2015) \\
\hline Fatty acids related compounds & Extract & Lima et al. $(2020)$ \\
\hline \multicolumn{3}{|l|}{ Amino acids } \\
\hline Glutamic acid & Pulp & Marx et al. (2002) \\
\hline Leucine & Pulp & Marx et al. (2002) \\
\hline Valine & Pulp & Marx et al. (2002) \\
\hline Phenylalanine & Pulp & Marx et al. (2002) \\
\hline Serine & Pulp & Marx et al. (2002) \\
\hline Tyrosin & Pulp & Marx et al. (2002) \\
\hline Alanine & Pulp & Marx et al. (2002) \\
\hline Threonine & Pulp & Marx et al. (2002) \\
\hline Proline & Pulp & Marx et al. (2002) \\
\hline Isoleucine & Pulp & Marx et al. (2002) \\
\hline Lysine & Pulp & Marx et al. (2002) \\
\hline Aspartic acid & Pulp & Marx et al. (2002) \\
\hline Asparagine & Pulp & Marx et al. (2002) \\
\hline Glycine & Pulp & Marx et al. (2002) \\
\hline Glutamine & Pulp & Marx et al. (2002) \\
\hline Arginine & Pulp & Marx et al. (2002) \\
\hline Histidine & Pulp & Marx et al. (2002) \\
\hline Methionine & Pulp & Marx et al. (2002) \\
\hline$\gamma$-Aminobutyric acid & Pulp & Marx et al. (2002) \\
\hline$\alpha$-Aminoadipic acid & Pulp & Marx et al. (2002) \\
\hline Amino acid related compounds & Extract & Lima et al. (2020) \\
\hline \multicolumn{3}{|l|}{ Biogenic amines } \\
\hline Ornithine & Pulp & Marx et al. (2002) \\
\hline Taurine & Pulp & Marx et al. (2002) \\
\hline Ethanolamine & Pulp & Marx et al. (2002) \\
\hline \multicolumn{3}{|l|}{ Vitamins } \\
\hline Ascorbic acid & Pulp and peel & Marx et al. (2002); Neves et al. (2015) \\
\hline$\alpha$-Tocopherol & Pulp & Marx et al. (2002) \\
\hline
\end{tabular}


Table 3 (Cont.). Chemical, nutritional and bioactive composition of Uxi (Endopleura uchi (Huber) Cuatrecasas).

\begin{tabular}{|c|c|c|}
\hline Components & Part of plant & References \\
\hline \multicolumn{3}{|l|}{ Minerals } \\
\hline $\mathrm{Mn}$ & Pulp, seed and peel & Marx et al. (2002); Berto et al. (2015) \\
\hline $\mathrm{Zn}$ & Pulp, seed and peel & Marx et al. (2002); Berto et al. (2015) \\
\hline $\mathrm{Cu}$ & Pulp, seed and peel & Marx et al. (2002); Berto et al. (2015) \\
\hline $\mathrm{Fe}$ & Pulp, seed and peel & Marx et al. (2002); Berto et al. (2015) \\
\hline $\mathrm{Mg}$ & Pulp, seed and peel & Marx et al. (2002); Berto et al. (2015) \\
\hline $\mathrm{Na}$ & Pulp, seed and peel & Marx et al. (2002); Berto et al. (2015) \\
\hline $\mathrm{P}$ & Pulp, seed and peel & Marx et al. (2002); Berto et al. (2015) \\
\hline \multicolumn{3}{|l|}{ Bioactive compounds } \\
\hline Phenolic Acid & Extract & Lima et al. $(2020)$ \\
\hline Total Phenolic Compounds & Tree bark extract, pulp and peel & $\begin{array}{l}\text { Neves et al. (2015); Silva and Teixeira (2015); } \\
\text { De Oliveira et al. (2017); Lima et al. (2020) }\end{array}$ \\
\hline Flavonoids & Extract & Lima et al. (2020) \\
\hline Chalcones & Extract & Lima et al. (2020) \\
\hline Coumarins & Extract & Lima et al. (2020) \\
\hline Others phenolic compounds & Extract & Lima et al. (2020) \\
\hline Terpenoids & Extract & Lima et al. (2020) \\
\hline Total flavonoids content & Tree bark extract & De Oliveira et al. (2017) \\
\hline \multicolumn{3}{|l|}{ Antioxidant activity } \\
\hline $\mathrm{AChE}$ and BuChE inhibitory activity & Tree bark extract & Silva and Teixeira (2015) \\
\hline Antibacterial activity & Tree bark extract & Silva and Teixeira (2015) \\
\hline$\alpha$-Glucosidase inhibitory activity & Tree bark extract & Silva and Teixeira (2015) \\
\hline
\end{tabular}

(Nunomura et al., 2009; Silva and Teixeira, 2015). The pulp and peel of the uxi showed great antioxidant potential, but similar to what occurs with vitamin $\mathrm{C}$ the storage time decreases this potential (Neves et al., 2015; Hyacienth et al., 2019). The principal carotenoid found in the uxi pulp is trans- $\beta$-carotene, which guarantees its potential as a functional food (Lima et al., 2020). It can also be considered a vitamin $\mathrm{E}$ source, as it has an amount higher than the daily intake recommended according to RDC n 269 of 2005 (Brasil, 2005).

\subsection{Pedra-ume caá (Eugenia punicifolia (Kunth) D.C.)}

Eugenia punicifolia (Kunth) D.C. belongs to the Myrtaceae family and is popularly known as pedra-umecaá, pedra-ume, murta, or muta. It is a shrub widely distributed in the Amazon region and the savanna biome (Périco et al., 2019). Pedra-ume caá (Eugenia punicifolia) is a fruit species used as an alternative source of functional food. The fruits are similar to a small cherry with sweet pulp, which presents different colors according to ripening stages (Ramos et al., 2019). The flowering season is from June to March, and fruiting can occur all year round (Souza and Lorenzi, 2008).

The species is characterized by a cylindrical stem, with bark in irregular plaques that expose the yellowcolored epidermis with light spots. The leaves are elliptical (approximately $6 \mathrm{~cm}$ long and $2 \mathrm{~cm}$ wide), opposite, and petiolate. Its numerous flowers are arranged in white panicles. The wood of this plant, when dry, is red and very resistant, being used in posts and rafters (Brito et al., 2014).
Eugenia punicifolia is one of the traditional medicinal plants unexplored by pharmacists in Brazil. Traditionally used by the local community, this species was registered by the French naturalist August de SaintHilaire on his travels to Brazilian territories from 1816 to 1822 (Brandão et al., 2012). Besides that, Eugenia punicifolia has agricultural and industrial importance due to its traditional medicinal applications as multiple biological activities, such as antioxidants (Cunha et al., 2016), antimicrobial (Santos et al. 2018), antiinflammatory (Costa et al., 2016; Lazarini et al., 2016), antinociceptive and gastroprotective (Basting et al., 2014), cytotoxic (Sousa et al., 2015) and insecticidal activities (Gonzalez et al., 2014). The leaves of this medicinal plant are popularly used in aqueous decoctions or infusions as a natural therapeutic agent for the treatment of inflammations, fever, and flu, diabetes, and in alcoholic infusions for the treatment of wounds and infectious diseases (Oliveira et al., 2005; Leite et al., 2010; Chaves and Barros, 2012; Perico et al., 2019). In addition to being a source of phenolic, flavonoid, essential oils (Linalool, $\beta$-caryophyllene, and $\alpha$ terpineol), coumarin, tannin, and galotanin (Basting et al., 2014; Galeno et al., 2014; Cunha et al., 2016; De Albuquerque et al., 2019).

Phytochemical studies carried out on the pulp and seed of the Eugenia punicifolia fruit demonstrated the occurrence of sucrose, $\alpha$-D-glucopyranose, $\beta$-Dglucopyranose, linoleic acid, gallic acid, shikimic acid, $\beta$ -glucogallic acid, 3'-rhamnoside myricetin, ellagic acid, quercetin 3-O-rhamnoside and kaempferol 7-O- 
rhamnoside (Ramos et al., 2019). From a pharmacological point of view, studies using crude extracts of this genus have shown its anti-inflammatory, analgesic, antifungal, antipyretic, hypotensive, antidiabetic, and antioxidant activities (Donepudi et al., 2012; Basting et al., 2014; Tenfen et al., 2016). Besides, the exotic flavor, juiciness, high acidity, and unique sensory characteristics of the fruit make it suitable for the production of juices, nectars, jams, and jellies (Lizcano et al., 2010; Calvi et al., 2017).

\subsection{Madroño (Garcinia madruno)}

Garcinia madruno is a species native to Central and South America, traditionally known as madroño, charichuelo, cozoiba, naranjita, ocoró, satro, and belongs the Clusiaceae family (Lim, 2012). It is a tropical fruit tree commonly grown in the Amazon region and easily found in its natural habitat, the Eastern Amazon, and in dry forests with sandy soils. Its trees are 6 to $12 \mathrm{~m}$ high, with a dense green crown, and the fruiting occurs in summer. This plant produces yellow fruit with one to three seeds, covered by a white pulp. The fruit is used as food and has a characteristic acidic flavor (Chávez Cury et al., 2012).

Garcinia madruno is widely used in the healing of skin infections and wounds due to its anti-inflammatory characteristics (Baggett et al., 2005). Also, it is a supplement to the diet of the local population due to the presence of proteins, lipids, carbohydrates, and minerals (Ca, Mg, Na, K, P, Fe, Zn, Cu, Mn) (Chávez Cury et al., 2012).

One of the reasons that aroused interest in Garcinia madruno is due to the presence of bioactive compounds previously identified in its leaves and fruits, such as vitamin $\mathrm{A}$, vitamin $\mathrm{C}$, total phenolic content, antioxidant activity, glyceryl palmitate, polyisoprenylated benzophenones, hydroxycitric acid, and biflavonoids (Osorio et al., 2013; Carrillo-Hormaza et al., 2016; Ramirez et al., 2019). In general, polyisoprenylated benzophenones show broad biological activity with antibacterial, antifungal, anti-inflammatory, and antioxidant properties (Kumar et al., 2013)

Garcinia madruno stands out for producing a high content of biflavonoids (6-11\%), establishing itself as a species of relevance because most fruits do not reach $8 \%$ (Tabares-Guevara et al., 2017; Sabogal-Guáqueta et al., 2018). Biflavonoids call attention compared to the other chemical groups in Garcinia due to their bioactive potential. Some studies show that these compounds can inhibit the lipid peroxidation of human LDL and stabilize the DPPH radical (Osorio et al., 2009; Osorio et al., 2013). Studies show that biflavonoids generally have a high level of antioxidant activity and relevant pharmacological activities, such as antimicrobial, antiallergic, anti-inflammatory, hepatoprotective antiviral (Ferreira et al., 2012; Carillo-Hormaza et al., 2019; Ramirez et al., 2019). However, although the functionality of biflavonoids is positively related to their antioxidant capacity, there is no evidence or studies that clarify the structural differences between biflavonoids with antioxidant activity (Carrillo-Hormaza et al., 2016).

\section{Future perspectives}

Given the vast bioavailability of Amazonian fruits, many are still unknown or little explored by the scientific community. However, several authors have been paying attention to this availability and have started investigating bioactive compounds' quantification in these exotic fruits. Information about the composition of exotic fruits from the Amazon is still scarce. Many of their bioactive compounds still need to be fully identified and characterized (phenolic acids, flavonoids, biflavonoids, anthocyanins, among others). Thus, more research must be carried out to determine the complete profile of the bioactive compounds.

Given the presence of essential phytochemicals in Amazonian fruits and their association with biological properties, these fruits' possible applications as functional ingredients of food products should be examined. Another point that needs to be explored more is the medicinal application of leaf extracts, fruit peels, and seeds in pharmacology and cosmetology. Finally, the use and enhancement of by-products (peel and seeds) produced during the processing of these fruits should be investigated once they can be a new source of valueadded ingredients. This can also help solve some environmental issues about the sustainable management of these materials.

\section{Conflict of interest}

The authors declare no conflicts of interest.

\section{Acknowledgments}

The authors thank the Coordination for the Improvement of Higher Education Personnel (CAPES, Brazil), for the financial support offered through scholarships and the National Council for Scientific and Technological Development (CNPq, Brazil).

\section{References}

Aguiar, J.P. and Do Amaral, F. (2015). Camu-camu (Myrciaria dubia HBK): yogurt processing, formulation, and sensory assessment. American 
Journal of Analytical Chemistry, 6(5), 377-381. https://doi.org/10.4236/ajac.2015.65036

Akachi, T., Shiina, Y., Kawaguchi, T., Kawagishi, H., Morita, T. and Sugiyama, K. (2010). 1-methylmalate from camu-camu (Myrciaria dubia) suppressed Dgalactosamine-induced liver injury in rats. Bioscience, Biotechnology, and Biochemistry, 74(3), 573-578. https://doi.org/10.1271/bbb.90775

Akter, M.S., Oh, S., Eun, J.B. and Ahmed, M. (2011), Nutritional compositions and health promoting phytochemicals of camu-camu (Myrciaria dubia) fruit: A review. Food Research International, 44(7), 1728-1732. https://doi.org/10.1016/ j.foodres.2011.03.045

Alves, R., Filgueiras, H., Moura, C., Araujo, N. and Almeida, A. (2002). Camu camu (Myrciaria dubia Mc Vaugh): a rich natural source of vitamin C. Proceedings of the Interamerican Society for Tropical Horticulture, 46(1), 11-13.

Andrade Júnior, M.C. and Andrade, J.S. (2014). Amazonian fruits: an overview of nutrients, calories and use in metabolic disorders. Food and Nutrition Sciences, 5(17), 1692-1703. https://doi.org/10.4236/ fns.2014.517182

Avila-Sosa, R., Montero-Rodríguez, A.F., AguilarAlonso, P., Vera-López, O., Lazcano-Hernández, M., Morales-Medina, J.C. and Navarro-Cruz, A.R. (2019). Antioxidant properties of Amazonian fruits: a mini review of in vivo and in vitro studies. Oxidative Medicine and Cellular Longevity, 2019, 8204129. https://doi.org/10.1155/2019/8204129

Baggett, S., Protiva, P., Mazzola, E.P., Yang, H., Ressler, E.T., Basile, M.J. and Kennelly, E.J. (2005). Bioactive benzophenones from Garcinia $\mathrm{x}$ antochymus fruits. Journal of Natural products, 68 (3), 354-360. https://doi.org/10.1021/np0497595

Baldini, T.F., Neri-Numa, I.A., Do Sacramento, C.K., Schmiele, M., Bolini, H.M.A., Pastore, G.M. and Bicas, J.L. (2017). Elaboration and Characterization of Apple Nectars Supplemented with Araçá-boi (Eugenia stipitata Mac Vaugh-Myrtaceae). Beverages, 3(4), 59. https://doi.org/10.3390/ beverages3040059

Barros, R.G.C., Andrade, J.K.S., Denadai, M., Nunes, M.L. and Narain, N. (2017). Evaluation of bioactive compounds potential and antioxidant activity in some Brazilian exotic fruit residues. Food Research International, 102, 84-92. https://doi.org/10.1016/ j.foodres.2017.09.082

Basting, R.T., Nishijima, C.M., Lopes, J.A., Santos, R.C., Périco, L.L., Laufer, S., Bauer, S., Costa, M.F., Santos, L.C., Rocha, L.R.M., Vilegas, W., Santos,
A.R.S., Dos Santos, C. and Hiruma-Lima, C.S. (2014). Antinociceptive, anti-inflammatory and gastroprotective effects of a hydroalcoholic extract from the leaves of Eugenia punicifolia (Kunth) DC. in rodents. Journal of Ethnopharmacology, 157, 257267. https://doi.org/10.1016/j.jep.2014.09.041

Berni, P., CampolI, S.S., Negri, T.C., DE Toledo, N.M. and Canniatti-Brazaca, S.G. (2019). NonConventional Tropical Fruits: Characterization, Antioxidant Potential and Carotenoid Bioaccessibility. Plant Foods for Human Nutrition, 74(1), 141-148. https://doi.org/10.1007/s11130-0180710-1

Berto, A., Da Silva, A.F., Visentainer, J.V., Matsushita, M. and De Souza, N.E. (2015). Proximate compositions, mineral contents and fatty acid compositions of native Amazonian fruits. Food Research International, 77(Part 3), 441-449. https:// doi.org/10.1016/j.foodres.2015.08.018

Bohry, D., Berilli, A.P.C.G., Da Silva Berilli, S., De Almeida, R.F. and Zooca, A.A.F. (2019). Characterization and genetic divergence of araçá-boi based on physicochemical and colorimetric traits of fruits. Revista de Ciências Agrárias Amazonian Journal of Agricultural and Environmental Sciences, 62, 3004. https://doi.org/10.22491/rca.2019.3004

Brandão, M. G., Pignal, M., Romaniuc, S., Grael, C.F. and Fagg, C.W. (2012). Useful Brazilian plants listed in the field books of the French naturalist Auguste de Saint-Hilaire (1779-1853). Journal of Ethnopharmacology, 143(2), 488-500. https:// doi.org/10.1016/j.jep.2012.06.052

Brazil. Ministry of Health. National Health Surveillance Agency. (2005). Resolution RDC $\mathrm{n}^{0}$ 269, of September 22, 2005. The "Technical regulation on the recommended daily intake (idr) of protein, vitamins and minerals". ANVISA - National Health Surveillance Agency, of September 23, 2005. Retrieved on August, 25, 2020 from BVMS Website: https://bvsms.saude.gov.br/bvs/saudelegis/ anvisa/2005/rdc0269 $22 \quad 09$ 2005.html.

Brito, A.U., Chaves, F.C.M., SenrA, T.V., Oka, J.M. and Berni, R.F. (2014). Production of fruits of stone-ume -caá according to weather conditions in Manaus-AM. In EMBRAPA Western Amazon-Article in conference proceedings (ALICE). Brazilian Horticulture, 31(2), S2373-S2379.

Calvi, G.P., Aud, F.F., Ferraz, I.D.K., Pritchard, H.W., and Kranner, I. (2017). Analyses of several seed viability markers in individual recalcitrant seeds of Eugenia stipitata McVaugh with totipotent germination. Plant Biology, 19(1), 6-13. https:// doi.org/10.1111/plb.12466 
Carrillo-Hormaza, L., Ramírez, A.M., Quintero-Ortiz, C., Cossio, M., Medina, S., Ferreres, F., GilIzquierdo, A. and Osorio, E. (2016). Comprehensive characterization and antioxidant activities of the main biflavonoids of Garcinia madruno: a novel tropical species for developing functional products. Journal of Functional Foods, 27, 503-516. https://doi.org/10.1016/j.jff.2016.10.001

Carrillo-Hormaza, L., Ramírez, A.M. and Osorio, E. (2019). Chemometric classification of Garcinia madruno raw material: Impact of the regional origin and ripeness stage of a neotropical exotic species. Food Chemistry, 293, 291-298. https:// doi.org/10.1016/j.foodchem.2019.04.118

Castro, J.C., Cobos, M., Maddox, J.D., Imán, S.A., Egoavil, A., Torres, J. and Gutierrez, F. (2015). Gene expression and enzyme activities of the Dmannose/L-galactose pathway influence L-ascorbic acid content in Myrciaria dubia. Biologia Plantarum, 59(4), 783-787. https://doi.org/10.1007/ s10535-015-0540-z

Castro, J.C., Maddox, J.D., Cobos, M., Requena, D., Zimic, M., Bombarely, A., Imán, S.A., Cerdeira, L.A. and Medina, A.E. (2015). De novo assembly and functional annotation of Myrciaria dubia fruit transcriptome reveals multiple metabolic pathways for L-ascorbic acid biosynthesis. BMC Genomics, 16, 997. https://doi.org/10.1186/s12864-015-2225-6

Castro, J.C., Maddox, J.D. and Imá, S.A. (2018). Camucamu-Myrciaria dubia (Kunth) McVaugh. In Rodrigues, S., de Oliveira Silva, E. and de Brito, E.S. (Eds). Exotic Fruits Reference Guide, p. 97-105. USA: Academic Press. https://doi.org/10.1016/B978 -0-12-803138-4.00014-9

Chagas, E.A., Bacelar-Lima, CG., Carvalho, A. D.S., Ribeiro, M.I.G., Sakazaki, R.T. and Neves, L.C. (2012). Camu-camu propagation (Myrciaria dubia (HBK) Mcvaugh).Agro@mbiente On-line,6(1),6773. https://doi.org/10.18227/19828470ragro.v6i1.634

Chang, S.K., Alasalvar, C. and Shahidi, F. (2019). Superfruits: Phytochemicals, antioxidant efficacies, and health effects-A comprehensive review. Critical Reviews in Food Science and Nutrition, 59(10), 1580 $-1604$. https:// doi.org/10.1080/10408398.2017.1422111

Chaves, E.M.F. and Barros, R.F.M. (2012). The executioner's diversity and use of medicinal resources in the Serra da Ibiapaba PAC, Piauí, Northeast Brazil. Brazilian Journal of Medicinal Plants, 14(3), 476-486. https://doi.org/10.1590/ S1516-05722012000300009

Chávez Cury, G., Abela Gisbert, M.D.C., Bravo, J.A.,
Peñarrieta, J.M. and Rendón Porcel, W.J. (2012). Study of the edible fruit of the plant species Garcinia madruno. Bolivian Journal of Chemistry, 29(1), 8793.

Chirinos, R., Galarza, J., Betalleluz-Pallardel, I., pedreschi, R. and Campos, D. (2010). Antioxidant compounds and antioxidant capacity of Peruvian camu camu (Myrciaria dubia (HBK) McVaugh) fruit at different maturity stages. Food Chemistry, 120(4), 1019-1024.

https://doi.org/10.1016/ j.foodchem.2009.11.041

Cuellar, F.A., Ariza, E., Anzola, C. and Restrepo, P. (2013). Research of antioxidant capacity of araza (Eugenia stipitata Mc Vaugh) during the ripening. Revista Colombiana de Química, 42(2), 21-28.

Cunha, F.A.B., Waczuk, E.P., Duarte, A.E., Barros, L.M., Elekofehinti, O.O., Matias, E.F.F., Da Costa, J. G.M., Sanmi, A.A., Boligon, A.A., Rocha, J.B.T., Souza, D.O., Posser, T., Coutinho, H.D.M., Franco, J.L. and Kamdem, J.P. (2016). Cytotoxic and antioxidative potentials of ethanolic extract of Eugenia uniflora L. (Myrtaceae) leaves on human blood cells. Biomedicine and Pharmacotherapy, 84, 614-621. https://doi.org/10.1016/

j.biopha.2016.09.089

Da Silva, F.C., Arruda, A., Ledel, A., Dauth, C., Romão, N.F., Viana, R.N., Ferraz, A.B.F., Picada, J.N. and Pereira, P. (2012). Antigenotoxic effect of acute, subacute and chronic treatments with Amazonian camu-camu (Myrciaria dubia) juice on mice blood cells. Food and Chemical Toxicology, 50(7), 22752281. https://doi.org/10.1016/j.fct.2012.04.021

De Abreu, H.A., Lago, I.A.D.S., Souza, G.P., PilóVeloso, D., Duarte, H.A. and Alcântara, A.F.D.C. (2008). Antioxidant activity of (+)-bergenin - a phytoconstituent isolated from the bark of Sacoglottis uchi Huber (Humireaceae). Organic and Biomolecular Chemistry, 6(15), 2713-2718. https:// doi.org/10.1039/b804385j

De Albuquerque, Y.A.P., Silva, J.R., Maciel, P.M.C. and Saraiva, R.A. (2019). Phytochemical characterization and allelopathic potential of the Eugenia punicifolia (Kunth) DC (Myrtaceae) extract on the germination and initial development of Lactuca sativa (Asteraceae). In 70th National Botany Congress $/ 36^{\circ}$ Northeast Botany Meeting. Vol. 1, p. 177-177. Maceió - Alagoas

Donepudi, A.C., Aleksunes, L.M., Driscoll, M.V., Seeram, N.P. and Slitt, A.L. (2012). The traditional ayurvedic medicine, Eugenia jambolana (Jamun fruit), decreases liver inflammation, injury and fibrosis during cholestasis. Liver International, 32 (4), 560-573. https://doi.org/10.1111/j.1478- 


\subsubsection{4.x}

EMBRAPA. Cultivars and Seeds Market. Brasília, DF: Amazônia is the birthplace of native fruits with high commercial potential, 2016. Retrieved on August, 25, 2020 from EMBRAPA Website: https:// www.EMBRAPA.br/busca-de-noticias/-/ noticia/14818376/amazonia-e-berco-de-frutasnativas-de-alto-potencial-comercial.

FAO, IFAD, UNICEF, OMS and PMA (2019). The state of food security and nutrition in the world 2019. Protect yourself from the slowdown and weakening of the economy. Retrieved on August, 26, 2020 from FAO Website: http://www.fao.org/3/ca5162es/ ca5162es.pdf.

FAO. (2020). Seguridad Alimentaria y Nutricional. Basic concepts. Special Program for Food Security (PESA). Retrieved on August, 25, 2020 from FAO Website: http://www.fao.org/3/a-at772s.pdf.

Ferreira, R.O., Carvalho, M.G.D. and Silva, T.M.S.D. (2012). Occurrence of biflavonoids in Clusiaceae: Chemical and pharmacological aspects. New Chemistry, 35(11), 2271-2277. https:// doi.org/10.1590/S0100-40422012001100035

Fidelis, M., De Oliveira, S.M., Santos, J.S., Escher, G.B., Rocha, R.S., Cruz, A.G. and Shahidi, F. (2020). From byproduct to a functional ingredient: Camucamu (Myrciaria dubia) seed extract as an antioxidant agent in a yogurt model. Journal of Dairy Science, 103(2), 1131-1140. https:// doi.org/10.3168/jds.2019-17173

Fracassetti, D., Costa, C., Moulay, L. and TomásBarberán, F.A. (2013). Ellagic acid derivatives, ellagitannins, proanthocyanidins and other phenolics, vitamin $\mathrm{C}$ and antioxidant capacity of two powder products from camu-camu fruit (Myrciaria dubia). Food Chemistry, 139(1-4), 578-588. https:// doi.org/10.1016/j.foodchem.2013.01.121

Fujita, A., Borges, K., Correia, R., De Melo Franco, B.D.G. and Genovese, M.I. (2013). Impact of spouted bed drying on bioactive compounds, antimicrobial and antioxidant activities of commercial frozen pulp of camu-camu (Myrciaria dubia Mc. Vaugh). Food Research International, 54 (1), 495-500. https://doi.org/10.1016/ j.foodres.2013.07.025

Gaglio, R., Gentile, C., Bonanno, A., Vintaloro, L., Perrone, A., Mazza, F., Barbaccia, P., Settanni, L. and Di Grigoli, A. (2019). Effect of saffron addition on the microbiological, physicochemical, antioxidant and sensory characteristics of yoghurt. International Journal of Dairy Technology, 72(2), 208-217. https://doi.org/10.1111/1471-0307.12569
Galeno, D.M.L., Carvalho, R.P., De Araújo Boleti, A.P., Lima, A.S., De Almeida, P.D.O., Pacheco, C.C., De Souza, T.P. and Lima, E.S. (2014). Extract from Eugenia punicifolia is an antioxidant and inhibits enzymes related to metabolic syndrome. Applied Biochemistry and Biotechnology, 172(1), 311-324. https://doi.org/10.1007/s12010-013-0520-8

Garzón, G.A., Narváez-Cuenca, C.E., Kopec, R.E., Barry, A.M., Riedl, K.M. and Schwartz, S.J. (2012). Determination of carotenoids, total phenolic content, and antioxidant activity of Arazá (Eugenia stipitata McVaugh), an Amazonian fruit. Journal of Agricultural and Food Chemistry, 60(18), 47094717. https://doi.org/10.1021/jf205347f

Gironés-Vilaplana, A., Baenas, N., Villaño, D., Speisky, H., García-Viguera, C. and Moreno, D.A. (2014). Evaluation of Latin-American fruits rich in phytochemicals with biological effects. Journal of Functional Foods, 7, 599-608. https:// doi.org/10.1016/j.jff.2013.12.025

Goncalves, A.E.S.S., Lajolo, F.M. and Genovese, M.I. (2010). Chemical composition and antioxidant/ antidiabetic potential of Brazilian native fruits and commercial frozen pulps. Journal of Agricultural and Food Chemistry, 58(8), 4666-4667. https:// doi.org/10.1021/jf903875u

Gonzalez, M.S., Lima, B.G., Oliveira, A.F., Nunes, D.D., Fernandes, C.P., Santos, M.G., Tietbohl, L.A.C., Mello, C.B., Rocha, L. and Feder, D. (2014). Effects of essential oil from leaves of Eugenia sulcataon the development of agricultural pest insects. Brazilian Journal of Pharmacognosy, 24(4), 413-418. https://doi.org/10.1016/j.bjp.2014.05.003

Hernández, M.S., CarrillO, M., Barrera, J. and FernándeZ-Trujillo, J.P. (2011). Camu-camu (Myrciaria dubia Kunth McVaugh). In Postharvest biology and technology of tropical and subtropical fruits, p. 352-375. USA: Woodhead Publishing. https://doi.org/10.1533/9780857092762.352

INPA. (2012). Cultivation of Camu-camu. Retrieved on August, 26, 2020 from INPA Website: https:// www.inpa.gov.br/cpca/areas/camu-camu.html.

Justi, K.C.J., Visentainer, J.V., De Souza, N.E. and Matsushita, M. (2000). Nutritional composition and vitamin C stability in stored camu-camu (Myrciaria dubia) pulp. Archivos Latinoamericanos de Nutrición, 50(4), 405-408.

Kaneshima, T., Myoda, T., Nakata, M., Fujimori, T., Toeda, K. and Nishizawa, M. (2016). Antioxidant activity of C-Glycosidic ellagitannins from the seeds and peel of camu-camu (Myrciaria dubia). LWTFood Science and Technology, 69, 76-81. https:// doi.org/10.1016/j.lwt.2016.01.024 
Klop, B., Elte, J.W.F. and Cabezas, M.C. (2013). Dyslipidemia in obesity: mechanisms and potential targets. Nutrients, 5(4), 1218-1240. https:// doi.org/10.3390/nu5041218

Kumar, R., Patel, D.K., Prasad, S.K., Laloo, D., Krishnamurthy, S. and Hemalatha, S. (2012). Type 2 antidiabetic activity of bergenin from the roots of Caesalpinia digyna Rottler. Fitoterapia, 83(2), 395401. https://doi.org/10.1016/j.fitote.2011.12.008

Kumar, S., Sharma, S. and Chattopadhyay, S.K. (2013). The potential health benefit of polyisoprenylated benzophenones from Garcinia and related genera: Ethnobotanical and therapeutic importance. Fitoterapia, 89, 86-125. https://doi.org/10.1016/ j.fitote.2013.05.010

Langley, P.C., Pergolizzi Jr, J.V., Taylor Jr, R. and Ridgway, C. (2015). Antioxidant and associated capacities of Camu camu (Myrciaria dubia): a systematic review. The Journal of Alternative and Complementary Medicine, 21(1), 8-14. https:// doi.org/10.1089/acm.2014.0130

Lazarini, J.G., Franchin, M., Infante, J., Paschoal, J.A.R., Freires, I.A., De Alencar, S.M. and Rosalen, P.L. (2016). Anti-inflammatory activity and polyphenolic profile of the hydroalcoholic seed extract of Eugenia leitonii, an unexplored Brazilian native fruit. Journal of Functional Foods, 26, 249-257. https:// doi.org/10.1016/j.jff.2016.08.001

Leite, P.E.C., De Almeida, K.B., Lagrota-Candido, J., Trindade, P., Da Silva, R.F., Ribeiro, M.G.L., LimaAraújo, K.G., Santos, W.C. and Quirico-Santos, T. (2010). Anti-inflammatory activity of Eugenia punicifolia extract on muscular lesion of $\mathrm{mdx}$ dystrophic mice. Journal of Cellular Biochemistry, 111(6), 1652-1660. https://doi.org/10.1002/ jcb.22906

Leite-LegattI, A.V., Batista, Â.G., Dragano, N.R.V., Marques, A.C., Malta, L.G., Riccio, M.F., Erbelin, M.N., Machado, A.R.T., Carvalho-Silva, L.B., Ruiz, A.L.T.G., De Carvalho, J.E., Pastore, G.M. and Júnior, M. R.M. (2012). Jaboticaba peel: Antioxidant compounds, antiproliferative and antimutagenic activities. Food Research International, 49(1), 596603. https://doi.org/10.1016/j.foodres.2012.07.044

Leterme, P., Buldgen, A., Estrada, F. and Londoño, A.M. (2006). Mineral content of tropical fruits and unconventional foods of the Andes and the rain forest of Colombia. Food Chemistry, 95(4), 644-652. https://doi.org/10.1016/j.foodchem.2005.02.003

Lim, T.K. (2012). Garcinia madruno. In Edible Medicinal and Non-Medicinal Plants, p. 76-79. Dordrecht, Netherlands: Springer. https:// doi.org/10.1007/978-94-007-1764-0_13
Lima Yamaguchi, K.K., Pereira, L.F.R., Lamarão, C.V., Lima, E.S. and da Veiga-Junior, V.F. (2015). Amazon acai: Chemistry and biological activities: A review. Food Chemistry, 179, 137-151. https:// doi.org/10.1016/j.foodchem.2015.01.055

Lima, L.G.B., Montenegro, J., Abreu, J.P.D., Santos, M.C.B., Nascimento, T.P.D., Santos, M.D.S., Ferreira, A.G., Cameron, L.C., Ferreira, M.S.L. and Teodoro, A.J. (2020). Metabolite Profiling by UPLC -MSE, NMR, and Antioxidant Properties of Amazonian Fruits: Mamey Apple (Mammea Americana), Camapu (Physalis Angulata), and Uxi (Endopleura Uchi). Molecules, 25(2), 342. https:// doi.org/10.3390/molecules25020342

Lizcano, L.J., Bakkali, F., Ruiz-Larrea, M.B. and RuizSanz, J.I. (2010). Antioxidant activity and polyphenol content of aqueous extracts from Colombian Amazonian plants with medicinal use. Food Chemistry, 119(4), 1566-1570. https:// doi.org/10.1016/j.foodchem.2009.09.043

Lunagariya, N.A., Patel, N.K., Jagtap, S.C. and Bhutani, K.K. (2014). Inhibitors of pancreatic lipase: State of the art clinical perspectives. EXCLI Journal, 13, 897 $-921$.

Malta, L.G., Ghiraldini, F.G., Reis, R., Do Vale Oliveira, M., Silva, L.B. and Pastore, G.M. (2012). In vivo analysis of antigenotoxic and antimutagenic properties of two Brazilian Cerrado fruits and the identification of phenolic phytochemicals. Food Research International, 49(1), 604-611. https:// doi.org/10.1016/j.foodres.2012.07.055

Marx, F., Andrade, E.A., Maria das Graças, B.Z. and Maia, J.S. (2002). Studies of edible Amazonian plants. Part 5: Chemical characterisation of Amazonian Endopleura uchi fruits. European Food Research and Technology, 214(4), 331-334. https:// doi.org/10.1007/s00217-001-0477-7

Matos, K.A.N., Lima, D.P., Barbosa, A.P.P., Mercadante, A.Z. and Chiste, R.C. (2019). Peels of tucumã (Astrocaryum vulgare) and peach palm (Bactris gasipaes) are by-products classified as very high carotenoid sources. Food Chemistry, 272, 216221. https://doi.org/10.1016/j.foodchem.2018.08.053

Ministry of the Environment. (2019) Brazilian Biodiversity. [online publication]. Retrieved on August, 26, 2020 from MMA Website: https:// www.mma.gov.br/biodiversidade/biodiversidadebrasileira.

Myoda, T., Fujimura, S., Park, B., Nagashima, T., Nakagawa, J. and Nishizawa, M. (2010). Antioxidative and antimicrobial potential of residues of camu-camu juice production. Journal of Food, Agriculture and Environment, 8(2), 304-307. 
Negri, T.C., Berni, P.R.A. and Brazaca, S.G.C. (2016). Nutritional value of native and exotic fruits from Brazil. Biosaúde, 18, 82-96.

Neri-Numa, I.A., Carvalho-Silva, L.B., Morales, J.P., Malta, L.G., Muramoto, M.T., Ferreira, J.E.M. and Pastore, G.M. (2013). Evaluation of the antioxidant, antiproliferative and antimutagenic potential of araçá -boi fruit (Eugenia stipitata Mc Vaugh-Myrtaceae) of the Brazilian Amazon Forest. Food Research International, 50(1), 70-76. https://doi.org/10.1016/ j.foodres.2012.09.032

Neves, L.C., de Campos, A.J., Colombo, R.C., Roberto, S.R. and Cisneros-Zevallos, L. (2017). Days after anthesis and postharvest behavior define maturity, harvesting time and nutraceutical content of camucamu fruit. Scientia Horticulturae, 224, 37-47. https://doi.org/10.1016/j.scienta.2017.04.031

Neves, L.C., Tosin, J.M., Benedette, R.M. and CIsnerosZevallos, L. (2015). Post-harvest nutraceutical behaviour during ripening and senescence of 8 highly perishable fruit species from the Northern Brazilian Amazon region. Food Chemistry, 174, 188 $-196$. https://doi.org/10.1016/ j.foodchem.2014.10.111

Nunomura, R., Oliveira, V.G., Da Silva, S.L. and Nunomura, S.M. (2009). Characterization of bergenin in Endopleura uchi bark and its antiinflammatory activity. Journal of the Brazilian Chemical Society, 20(6), 1060-1064. https:// doi.org/10.1590/S0103-50532009000600009

Oliveira, G.R., Simão, A.A., Pereira, L.L., Rocha, F.D., Raposo, N.R., De Oliveira, V.I., Pereira, T.V., Do Carmo, H.P., Oliveira, T.C., De Sousa, O.V., De Araujo, A.L.A. and Yamamoto, C.H. (2017). Stem bark extracts of Endopleura uchi (Huber) Cuatrec: Inhibition of pancreatic lipase and antioxidant activity. Journal of Medicinal Plants Research, 11 (30), 472-479. https://doi.org/10.5897/ JMPR2016.6271

Oliveira, R.N., Dias, I.J. and Câmara, C.A. (2005). Comparative study of the essential oil of Eugenia punicifolia (HBK) DC. from different locations in Pernambuco. Brazilian Journal of Pharmacognosy, 15(1), 39-43. https://doi.org/10.1590/S0102695X2005000100009

Osorio, E., Montoya, G. and Bastida, J. (2009). Phytochemical characterization of a biflavonoid fraction from Garcinia madruno: inhibition of human LDL oxidation and its free radical scavenging mechanism. Vitae, 16(3), 369-377.

Osorio, E., Londoño, J. and Bastida, J. (2013). Lowdensity lipoprotein (LDL)-antioxidant biflavonoids from Garcinia madruno. Molecules, 18(5), 6092-
6100. https://doi.org/10.3390/molecules 18056092

Pereira, C.A., Corrêa, A.D., Pereira, L.L.S., Chagas, P.M.B., Santos, C.D. and de Souza, S.P. (2011). Inhibition of digestive enzymes by commercial powder extracts of Hoodia gordonii used to treat obesity. Brazilian Journal of Biosciences, 9(3), 265269.

Périco, L.L., Rodrigues, V.P., Ohara, R., Nunes, V.V.A., Da Rocha, L.R.M., VilegaS, W., Dos Santos, C., Hiruma-Lima, C.A. (2019). Can the gastric healing effect of Eugenia punicifolia be the same in male and female rats? Journal of Ethnopharmacology, 235, 268-278. https://doi.org/10.1016/ j.jep.2019.02.012

Politi, F.A., de Mello, J.C., Migliato, K.F., Nepomuceno, A.L., Moreira, R.R. and Pietro, R.C. (2011). Antimicrobial, cytotoxic and antioxidant activities and determination of the total tannin content of bark extracts Endopleura uchi. International Journal of Molecular Sciences, 12(4), 2757-2768. https:// doi.org/10.3390/ijms 12042757

Ramirez, C., Gil, J.H., Marín-Loaiza, J.C., Rojano, B. and Durango, D. (2019). Chemical constituents and antioxidant activity of Garcinia madruno (Kunth) Hammel. Journal of King Saud University-Science, 31(4), 1283-1289. https://doi.org/10.1016/ j.jksus.2018.07.017

Ramos, A.S., Mar, J.M., Da Silva, L.S., Acho, L.D., Silva, B.J.P., Lima, E.S., Campelo, P.H., Sanches, E.A., Bezerra, J.A., Chaves, F.C.M., Campos, F.R. and Machado, M.B. (2019). Pedra-ume caá fruit: an Amazon cherry rich in phenolic compounds with antiglycant and antioxidant properties. Food Research International, 123, 674-683. https:// doi.org/10.1016/j.foodres.2019.05.042

Reynertson, K.A., Yang, H., Jiang, B., Basile, M.J. and Kennelly, E.J. (2008). Quantitative analysis of antiradical phenolic constituents from fourteen edible Myrtaceae fruits. Food Chemistry, 109(4), 883-890.

https://doi.org/10.1016/

j.foodchem.2008.01.021

Rodrigues, R.B. and Marx, F. (2006). Camu camu [Myrciaria dúbia (HBK) Mc Vaugh]: a promising fruit from the Amazon Basin. Nutrition Vienna, 30 (9), 376.

Rufino, M.S.M., Alves, R.E., Brito, E.S., Perez-Jimenez, J., Saura-Calixto, F. and Mancinifilho, J. (2010). Bioactive compounds and antioxidant capacities of 18 non-traditional tropical fruits from Brazil. Food Chemistry, 121(4), 996-10002. https:// doi.org/10.1016/j.foodchem.2010.01.037

Sá, B.M., Lima, C.S., Silva, U.D.A., Carvalho, H.O., Fernandes, C.P., Resque, R.L., De Oliveira, T.T. and 
Carvalho, J.C.T. (2015). Subchronic toxicity evaluation of the hydroethanolic extract from Endopleura uchi (Huber) Cuatrec in Wistar rats. African Journal of Pharmacy and Pharmacology, 9 (8), 223-229. https://doi.org/10.5897/AJPP2014.4220

Sabogal-Guáqueta, A.M., Carrillo-Hormaza, L., Osorio, E. and Cardona-Gómez, G.P. (2018). Effects of biflavonoids from Garcinia madruno on a triple transgenic mouse model of Alzheimer's disease. Pharmacological Research, 129, 128-138. https:// doi.org/10.1016/j.phrs.2017.12.002

Santos, J.F.S., Rocha, J.E., Bezerra, C.F., Do Nascimento Silva, M.K., De Matos, Y.M.L.S., De Freitas, T.S., Dos Santos, A.T.L., Da Cruz, R.P., Machado, A.J.T., Rodrigues, T.H.S., De Brito, E.S., Sales, D.L., Almeida, W.O., Da Costa, J.G.M., Coutinho, H.D.M. and Morais-Braga, M.F.B. (2018). Chemical composition, antifungal activity and potential antivirulence evaluation of the Eugenia uniflora essential oil against Candida spp. Food Chemistry, 261, 233239. https://doi.org/10.1016/j.foodchem.2018.04.015

Shikov, A.N., Pozharitskaya, O.N., Makarova, M.N., Kovaleva, M.A., Laakso, I., Dorman, H.D., Hiltunen, R., Makarov, V.G. and Galambosi, B. (2012). Effect of Bergenia crassifolia L. extracts on weight gain and feeding behavior of rats with high-caloric dietinduced obesity. Phytomedicine, 19(14), 1250-1255. https://doi.org/10.1016/j.phymed.2012.09.019

Silva, L.R. and Teixeira, R. (2015). Phenolic profile and biological potential of Endopleura uchi extracts. Asian Pacific Journal of Tropical Medicine, 8(11), 889-897. https://doi.org/10.1016/j.apjtm.2015.10.013

Silva, S.L.D., Oliveira, V.G.D., Yano, T. and Nunomura, R.D.C.S. (2009). Antimicrobial activity of bergenin from Endopleura uchi (Huber) Cuatrec. Acta amazônica, 39(1), 187-191. https://doi.org/10.1590/ S0044-59672009000100019

Soares, J.C., Rosalen, P.L., Lazarini, J.G., Massarioli, A.P., Da Silva, C.F., Nani, B.D. and De Alencar, S.M. (2019). Comprehensive characterization of bioactive phenols from new Brazilian superfruits by LC-ESI-QTOF-MS, and their ROS and RNS scavenging effects and anti-inflammatory activity. Food Chemistry, 281, 178-188. https:// doi.org/10.1016/j.foodchem.2018.12.106

Sousa, R.M.F., De Morais, S.A., VIeira, R.B., Napolitano, D.R., Guzman, V.B., Moraes, T.S., Cunha, L.C. S., Martins, C.H.G., Chang, R., Aquino, F.J.T., Do Nascimento, E.A. and De Oliveira, A. (2015). Chemical composition, cytotoxic, and antibacterial activity of the essential oil from Eugenia calycina Cambess. leaves against oral bacteria. Industrial Crops and Products, 65, 71-78. https:// doi.org/10.1016/j.indcrop.2014.11.050

Souza, S.P.D., Pereira, L.L., Souza, A.A. and Santos, C.D.D. (2011). Inhibition of pancreatic lipase by extracts of Baccharis trimera (Less.) DC., Asteraceae: evaluation of antinutrients and effect on glycosidases. Revista Brasileira de Farmacognosia, 21(3), 450-455. https:// doi.org/10.1590/S0102-695X2011005000049

Souza, V.C. and Lorenzi, H. (2008). Systematic botany: Illustrated guide for identifying families of native and exotic phanerogams in Brazil in APG II. 2nd ed. Nova Odessa, Brazil: Instituto Plantarum,

Sukhdev, S. and Singh, K.S. (2013). Therapeutic role of phytomedicines on obesity: importance of herbal pancreatic lipase inhibitors. International Research Journal of Medical Sciences, 1(9), 15-26.

Tabares-Guevara, J.H., Lara-Guzmán, O.J., LondoñoLondoño, J.A., Sierra, J.A., León-Varela, Y.M., Álvarez-Quintero, R.M., Osorio, E.J. and RamirezPineda, J.R. (2017). Natural Biflavonoids Modulate Macrophage-Oxidized LDL Interaction In Vitro and Promote Atheroprotection In Vivo. Frontiers in Immunology, 8, 923. https://doi.org/10.3389/ fimmu.2017.00923

Taveira, M., Silva, L.R., Vale-Silva, L.A., Pinto, E., Valentao, P., Ferreres, F., Pinho, P.G. and Andrade, P.B. (2010). Lycopersicon esculentum seeds: an industrial byproduct as an antimicrobial agent. Journal of Agricultural and Food Chemistry, 58(17), 9529-9536. https:// doi.org/10.1021/jf102215g

Tenfen, A., Siebert, D.A., Yamanaka, C.N., Mendes de Córdova, C.M., Scharf, D.R., Simionatto, E.L. and Alberton, M.D. (2016). Chemical composition and evaluation of the antimicrobial activity of the essential oil from leaves of Eugenia platysema. Natural Product Research, 30(17), 2007-2011. https://doi.org/10.1080/14786419.2015.1107056

Ueda, H., Kuroiwa, E., Tachibana, Y., Kawanishi, K., Ayala, F. and Moriyasu, M. (2004). Aldose reductase inhibitors from the leaves of Myrciaria dubia (HB and K.) McVaugh. Phytomedicine, 11(7-8), 652-656. https://doi.org/10.1016/j.phymed.2003.12.002

Viana, E.S., Jesus, J.L., Reis, R.C., Fonseca, M.D. and Sacramento, C.K. (2012). Physicochemical and sensory characterization of papaya jam with araçáboi. Brazilian Journal of Orcharding, 34(4), 1154$1164 . \quad$ https://doi.org/10.1590/S010029452012000400024

Vidigal, M.C., Minim, V.P., Carvalho, N.B., Milagres, M.P. and Gonçalves, A.C. (2011). Effect of a health claim on consumer acceptance of exotic Brazilian fruit juices: Açaí (Euterpe oleracea Mart.), Camu- 
camu (Myrciaria dubia), Caja (Spondias lutea L.) and Umbu (Spondias tuberosa Arruda). Food Research International, 44(7), 1988-1996. https:// doi.org/10.1016/j.foodres.2010.11.028

Vinholes, J., Grosso, C., Andrade, P.B., Gil-Izquierdo, A., Valentão, P., de Pinho, P.G. and Ferreres, F. (2011). In vitro studies to assess the antidiabetic, anti -cholinesterase and antioxidant potential of Spergularia rubra. Food Chemistry, 129(2), 454-462. https://doi.org/10.1016/j.foodchem.2011.04.098

Yazawa, K., Suga, K., Honma, A., Shirosaki, M. and Koyama, T. (2011). Anti-inflammatory effects of seeds of the tropical fruit camu-camu (Myrciaria dubia). Journal of Nutritional Science and Vitaminology, 57(1), 104-107. https:// doi.org/10.3177/jnsv.57.104

Yun, J.W. (2010). Possible anti-obesity therapeutics from nature-A review. Phytochemistry, 71(14-15), 16251641. https://doi.org/10.1016/ j.phytochem.2010.07.011

Zanatta, C.F. and Mercadante, A.Z. (2007). Carotenoid composition from the Brazilian tropical fruit camucamu (Myrciaria dubia). Food Chemistry, 101(4), 1526-1532. https://doi.org/10.1016/ j.foodchem.2006.04.004

Zapata, S.M. and Dufour, J.P. (1993). Camu - camu Myrciaria dubia (HBK) McVaugh: Composição química da fruta. Journal of the Science of Food and Agriculture, 61(3), 349-351. https://doi.org/10.1002/ jsfa. 2740610310

Zikiou, A. and Zidoune, M.N. (2019). Enzymatic extract from flowers of Algerian spontaneous Cynara cardunculus: Milk-clotting properties and use in the manufacture of a Camembert-type cheese. International Journal of Dairy Technology, 72(1), 89-99. https:// doi.org/10.1111/1471-0307.12563 